\title{
THE ROLE OF TRANSFORMATIONAL LEADERSHIP AND KNOWLEDGE MANAGEMENT IN HUMAN CAPITAL AND ITS IMPLICATIONS ON THE PERFORMANCE OF THE ACEH FINANCIAL MANAGEMENT AGENCY
}

\author{
Yayang Safriyanti, Said Musnadi and Teuku Roli Ilhamsyah Putra \\ Management Department, Universitas Syiah Kuala, Indonesia \\ http://doi.org/10.35409/IJBMER.2021.3269
}

\begin{abstract}
This study intends to examine the role of transformational leadership and knowledge management in human capital and its implications for the performance of the Aceh Financial Management Agency (BPKA). The population of this research is all civil servants (PNS) at BPKA, amounting to 378 people. This research established Stratified Proportional Random Sampling as a method of sampling based on the BPKA work unit group so that 131 people were obtained as a sample. Data were collected using a questionnaire and analyzed using the Structural Equation Modeling (SEM) method. The results of the descriptive hypothesis testing prove that transformational leadership, knowledge management, human capital, and organizational performance at BPKA are good. The results of direct hypothesis testing prove that transformational leadership and knowledge management have a significant effect on human capital, and transformational leadership, knowledge management, and human capital have a significant effect on BPKA organizational performance. The results of hypothesis testing indirectly prove that human capital plays a role as partial mediation both in mediating the role of transformational leadership on organizational performance and in mediating knowledge management on organizational performance at BPKA. All of these results prove that modeling to improve BPKA's organizational performance can be used. This can be a reference both academically and practically. Further researchers can use this proven research model for further research development, by adding other variables such as organizational citizenship behavior (OCB) and high-performance working systems (HPWS).
\end{abstract}

Keyword: Transformational Leadership, Knowledge Management, Human Capital, Organizational Performance.

\section{INTRODUCTION}

As one of the regions that has obtained autonomy rights and in facing these challenges and dynamics, the Aceh Government continues to strive to be more responsive in facing the various demands for change that exist. For this reason, regional apparatuses within the Aceh Government are required to be able to display optimal organizational performance for the smooth running of the government and the implementation of national development in accordance with statutory regulations.

In realizing the Presidential Instruction Number 7 of 1999, the Aceh Financial 


\section{International Journal of Business Management and Economic Review}

Vol. 4, No. 03; 2021

ISSN: 2581-4664

Management Agency (BPKA) as one of the Indonesian Government institutions in Aceh, has taken policy steps to run the wheels of government as stated in the 2017-2022 BPKA Strategic Plan. BPKA is the Aceh government institutionwhichcarry out the government and development affairs in the field of regional financial management, led by a Head of the Agency, and are under and responsible to the ACEH Governor through the Regional Secretary. The main task, function, and authority of BPKA are to carry out government tasks in the field of Aceh revenue, the budget sector, the management of Aceh's assets, the treasury sector, the accounting sector, the development and evaluation of district/city budgets following the provisions of the prevailing laws and regulations.

Based on data of the Government Agency Performance Accountability Report (LAKIP) 2016-2019, BPKA has achievement targets as in Table 1 below:

Table 1. Comparison between BPKA's Realized Performance in 2016 to 2019

\begin{tabular}{|c|c|c|c|c|c|c|c|c|}
\hline \multirow[b]{2}{*}{ Indicator } & \multicolumn{2}{|c|}{ In 2016} & \multicolumn{2}{|c|}{ In 2017} & \multicolumn{2}{|c|}{ In 2018} & \multicolumn{2}{|c|}{ In 2019} \\
\hline & $\begin{array}{l}\text { Tar } \\
\text { get }\end{array}$ & $\begin{array}{l}\text { Reali } \\
\text { zation }\end{array}$ & $\begin{array}{l}\text { Tar } \\
\text { get }\end{array}$ & $\begin{array}{l}\text { Reali } \\
\text { zation }\end{array}$ & $\begin{array}{l}\text { Tar } \\
\text { get }\end{array}$ & $\begin{array}{l}\text { Real } \\
\text { izati } \\
\text { on }\end{array}$ & $\begin{array}{l}\text { Targe } \\
\mathbf{t}\end{array}$ & $\begin{array}{l}\text { Reali } \\
\text { zation }\end{array}$ \\
\hline $\begin{array}{l}\text { Percentage } \text { (increase) of } \\
\text { Aceh's original income } \\
\text { (PAD) }\end{array}$ & - & - & $14 \%$ & $1.63 \%$ & $25 \%$ & $\begin{array}{l}16.1 \\
9 \%\end{array}$ & $14 \%$ & $16 \%$ \\
\hline $\begin{array}{l}\text { Percentage of Aceh's Tax } \\
\text { Contribution to PAD }\end{array}$ & - & - & $60 \%$ & $\begin{array}{l}60.65 \\
\% \\
\end{array}$ & - & - & - & - \\
\hline $\begin{array}{l}\text { Percentage of Aceh Province } \\
\text { Institutions (SKPAs) that } \\
\text { submit annual financial } \\
\text { reports on time }\end{array}$ & $\begin{array}{l}100 \\
\%\end{array}$ & $96 \%$ & $\begin{array}{l}100 \\
\%\end{array}$ & $\begin{array}{l}97.96 \\
\%\end{array}$ & $\begin{array}{l}100 \\
\%\end{array}$ & $\begin{array}{l}100 \\
\%\end{array}$ & $90 \%$ & $81 \%$ \\
\hline $\begin{array}{l}\text { Percentage of increase in } \\
\text { Aceh's original revenue } \\
\text { realization }\end{array}$ & - & - & $2 \%$ & $1.63 \%$ & $2 \%$ & $\begin{array}{l}1.48 \\
\%\end{array}$ & - & - \\
\hline $\begin{array}{l}\text { Number of APBK documents } \\
\text { and accountability for Aceh } \\
\text { Expenditure budget (APBK) } \\
\text { that are evaluated on time } \\
\text { (District / City) }\end{array}$ & - & - & 23 & 23 & 23 & 23 & 23 & 23 \\
\hline $\begin{array}{l}\text { Aceh's original revenue } \\
\text { contribution percentage to } \\
\text { APBA }\end{array}$ & - & - & $15 \%$ & $\begin{array}{l}14.04 \\
\%\end{array}$ & $17 \%$ & $\begin{array}{l}15.3 \\
1 \%\end{array}$ & $15 \%$ & $\begin{array}{l}15.71 \\
\%\end{array}$ \\
\hline $\begin{array}{l}\text { Number of Samsat Service } \\
\text { Innovations }\end{array}$ & - & - & 2 & 3 & 3 & 4 & 2 & 4 \\
\hline $\begin{array}{l}\text { Percentage of revaluation of } \\
\text { assets that do not have value }\end{array}$ & - & - & $20 \%$ & $25 \%$ & $50 \%$ & $76 \%$ & $\begin{array}{l}211 \\
\text { Unit } \\
\end{array}$ & 0 \\
\hline Percentage of securing Aceh & - & - & $60 \%$ & 31.26 & $7 \%$ & $3 \%$ & 25 & 18 \\
\hline
\end{tabular}


Vol. 4, No. 03; 2021

ISSN: 2581-4664

\begin{tabular}{|l|l|l|l|l|l|l|l|l|}
\hline \hline \multirow{2}{*}{ Indicator } & \multicolumn{2}{|l|}{ In 2016 } & \multicolumn{2}{l|}{ In 2017 } & \multicolumn{2}{l|}{ In 2018 } & \multicolumn{2}{l|}{ In 2019 } \\
\cline { 2 - 10 } & $\begin{array}{l}\text { Tar } \\
\text { get }\end{array}$ & $\begin{array}{l}\text { Reali } \\
\text { zation }\end{array}$ & $\begin{array}{l}\text { Tar } \\
\text { get }\end{array}$ & $\begin{array}{l}\text { Reali } \\
\text { zation }\end{array}$ & $\begin{array}{l}\text { Tar } \\
\text { get }\end{array}$ & $\begin{array}{l}\text { Real } \\
\text { izati } \\
\text { on }\end{array}$ & $\begin{array}{l}\text { Targe } \\
\text { t }\end{array}$ & $\begin{array}{l}\text { Reali } \\
\text { zation }\end{array}$ \\
\hline government's land assets & & & & $\%$ & & & & \\
\hline $\begin{array}{l}\text { Percentage of capitalized } \\
\text { document ownership of Aceh } \\
\text { property }\end{array}$ & - & - & $60 \%$ & $\begin{array}{l}78.83 \\
\% \%\end{array}$ & $11 \%$ & $26 \%$ & - & - \\
\hline $\begin{array}{l}\text { Percentage of write-offs and } \\
\text { transfers of Aceh government } \\
\text { assets in districts/cities }\end{array}$ & - & - & $30 \%$ & $1.94 \%$ & $30 \%$ & $\begin{array}{l}20.5 \\
4 \%\end{array}$ & - & - \\
\hline $\begin{array}{l}\text { Percentage of idle asset } \\
\text { utilization/usage }\end{array}$ & - & $20 \%$ & $0 \%$ & $10 \%$ & 0 & - & - \\
\hline $\begin{array}{l}\text { Percentage of non-cash } \\
\text { transactions against Aceh's } \\
\text { budget for revenues and } \\
\text { expenditures }\end{array}$ & - & - & - & - & $70 \%$ & 91.4 & - & - \\
\hline $\begin{array}{l}\text { Number of Districts / Cities } \\
\text { implementing Regional } \\
\text { Financial Information System } \\
\text { (Reg-SIKD) }\end{array}$ & - & - & 23 & 3 & 17 & 18 & 23 & 23 \\
\hline
\end{tabular}

Source: LAKIP BPKA

From the LAKIP of BPKA data above, it is known that there are still many activities whose performance realization has reached the target. These results indicate that the organizational performance of BPKA is still not optimal. The performance of BPKA as a public sector organization is not only measured by means of work contracts signed by the head of the agency at the beginning of each year but also measured through budget absorption. Table 2 below shows the performance of the BPKA budget from 2016 to 2019.

Table 2. Budget Performance

\begin{tabular}{|c|c|c|c|c|c|c|c|c|}
\hline \multirow[b]{2}{*}{ Indicator } & \multicolumn{2}{|c|}{ In 2016} & \multicolumn{2}{|c|}{ In 2017} & \multicolumn{2}{|c|}{ In 2018} & \multicolumn{2}{|c|}{ In 2019} \\
\hline & $\begin{array}{l}\text { Targe } \\
t\end{array}$ & $\begin{array}{l}\text { Reali } \\
\text { zation }\end{array}$ & $\begin{array}{l}\text { Tar } \\
\text { get }\end{array}$ & $\begin{array}{l}\text { Reali } \\
\text { zation }\end{array}$ & $\begin{array}{l}\text { Tar } \\
\text { get }\end{array}$ & \begin{tabular}{|l|} 
Real \\
izati \\
on
\end{tabular} & $\begin{array}{l}\text { Targe } \\
t\end{array}$ & $\begin{array}{l}\text { Reali } \\
\text { zation }\end{array}$ \\
\hline $\begin{array}{l}\text { Improve the quality of } \\
\text { regional } \\
\text { management in an orderly, } \\
\text { effective, and efficient } \\
\text { manner according to } \\
\text { regulations }\end{array}$ & $\begin{array}{l}14.36 \\
8.473 . \\
750\end{array}$ & $\begin{array}{l}88.25 \\
\%\end{array}$ & $\begin{array}{l}16.6 \\
02.5 \\
18.5 \\
00\end{array}$ & $\begin{array}{l}66.25 \\
\%\end{array}$ & $\begin{array}{l}20,1 \\
82,0 \\
85,6 \\
77\end{array}$ & $\begin{array}{l}72.3 \\
3 \%\end{array}$ & $\begin{array}{l}20.71 \\
0.908 . \\
562\end{array}$ & $84 \%$ \\
\hline Improve the quality of & 3.009 . & 90.76 & 1.90 & $87 \%$ & 2.95 & 96.4 & 3.930. & $95 \%$ \\
\hline
\end{tabular}


International Journal of Business Management and Economic Review

Vol. 4, No. 03; 2021

ISSN: 2581-4664

\begin{tabular}{|c|c|c|c|c|c|c|c|c|}
\hline \multirow[b]{2}{*}{ Indicator } & \multicolumn{2}{|c|}{ In 2016} & \multicolumn{2}{|c|}{ In 2017} & \multicolumn{2}{|c|}{ In 2018} & \multicolumn{2}{|c|}{ In 2019} \\
\hline & $\begin{array}{l}\text { Targe } \\
t\end{array}$ & $\begin{array}{l}\text { Reali } \\
\text { zation }\end{array}$ & $\begin{array}{l}\text { Tar } \\
\text { get }\end{array}$ & $\begin{array}{l}\text { Reali } \\
\text { zation }\end{array}$ & $\begin{array}{l}\text { Tar } \\
\text { get }\end{array}$ & $\begin{array}{l}\text { Real } \\
\text { izati } \\
\text { on }\end{array}$ & $\begin{array}{l}\text { Targe } \\
\mathbf{t}\end{array}$ & $\begin{array}{l}\text { Reali } \\
\text { zation }\end{array}$ \\
\hline $\begin{array}{ll}\text { district/city } & \text { financial } \\
\text { management } & \end{array}$ & $\begin{array}{l}786.0 \\
00\end{array}$ & $\%$ & $\begin{array}{l}0.38 \\
4.40 \\
0 \\
\end{array}$ & & $\begin{array}{l}9.87 \\
0.00 \\
0\end{array}$ & $9 \%$ & $\begin{array}{l}665.0 \\
00\end{array}$ & \\
\hline $\begin{array}{l}\text { Orderly Asset Management } \\
\text { Administration }\end{array}$ & - & - & $\begin{array}{l}4.50 \\
1.84 \\
1.40 \\
0\end{array}$ & $\begin{array}{l}44.24 \\
\%\end{array}$ & $\begin{array}{l}3,63 \\
7.49 \\
2.00 \\
0\end{array}$ & $\begin{array}{l}44.8 \\
0 \%\end{array}$ & $\begin{array}{l}6.338 \\
080.1 \\
23\end{array}$ & $75 \%$ \\
\hline $\begin{array}{ll}\text { Integrated } & \text { district/city } \\
\text { financial data } & \end{array}$ & - & - & $\begin{array}{l}665 . \\
208 . \\
000\end{array}$ & $\begin{array}{l}60.61 \\
\%\end{array}$ & $\begin{array}{l}757 . \\
240 . \\
000\end{array}$ & $\begin{array}{l}86.7 \\
5 \%\end{array}$ & $\begin{array}{l}3.930 \\
665.0 \\
00\end{array}$ & $95 \%$ \\
\hline $\begin{array}{ll}\text { Orderly Aceh } & \text { Financial } \\
\text { Management } & \\
\text { Administration } & \end{array}$ & - & - & 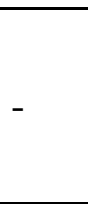 & - & $\begin{array}{l}3.27 \\
0.46 \\
5.00 \\
0\end{array}$ & $\begin{array}{l}80.1 \\
0 \%\end{array}$ & $\begin{array}{l}3.255 \\
665.0 \\
00\end{array}$ & $90 \%$ \\
\hline
\end{tabular}

Source: LAKIP BPKA

Based on the LAKIP, it can be seen that the quality of employee performance is not too optimal. These phenomena and figures show that the performance of BPKA as a public organization is still not optimal. In terms of budget absorption, it is also known that BPKA's performance is still not good, where through the table above it can be seen that from 2016 to 2019, none of the budget components reached 100\% absorption. BPKA's performance is not maximal, as the author quotes from(Modus-Aceh, 2019)From this realization, the DPRA concluded that there was no maximum effort from the Head of BPKA to boost Aceh Original Income (PAA).

Another thing that causes BPKA's not optimal performance as described in the LAKIP BPKA report is the limited facilities and infrastructure for services and support for the implementation of tasks. Furthermore, the quality of human resources owned by BPKA is still weak so that Aceh's income has not contributed significantly to the amount of expenditure each year so that Aceh is still very dependent on transfer income. the income sector in order to prepare itself from the dependence of the regions on revenues from special autonomy, as well as the quality of human resources in the financial management sector are also felt to be weak. These things are one of the reasons that BPKA's performance is still not optimal.

The low realization in terms of the percentage of the security of the Aceh government's land assets is due to a lack of coordination with the District / City government land institution (BPN) in certifying the use rights of the Aceh government. Another phenomenon that causes BPKA's performance to be not optimal is due to the disorderly administration and timeliness of reporting the deletion and maturation of assets, the lack of supporting data which is a requirement for BPKA grants according to Permendagri No. this transfer.

Another phenomenon that occurs in the institutional and regulatory sector in the form of the BPKA organizational structure stipulated by the Governor of Aceh Regulation Number 66 of 


\section{International Journal of Business Management and Economic Review}

Vol. 4, No. 03; 2021

ISSN: 2581-4664

2018 has not been able to accommodate the duties and functions of BPKA, especially the task of information technology and the budget sector, especially after the issuance of Permendagri Number 5 of 2017 which mandates the compilation task. KUA-PPAS is the obligation of BPKA. The number of new regulations issued by the central government resulted in local governments having to keep adjusting. The incomplete legal umbrella in carrying out tasks such as SOPs and adequate financial management systems and procedures.

BPKA still needs hard work and smart work by mobilizing all available resources to achieve organizational goals, both human resources, technology, supporting facilities, and a conducive work environment that can support the performance of employees in achieving better organizational performance outputs. From the LAKIP of BPKA mentioned above, it can be summarized that the performance of BPKA as a public sector organization is still not satisfactory. This indicates that the performance of the agencies applied to BPKA has not been recognized for its superiority. The performance of government agencies is not only measured from the perspective of budget absorption, but also through employee performance. The organization will face obstacles in achieving goals when the performance of employees is ineffective, in the sense that it cannot meet the job demands desired by the organization.

\section{LITERATURE STUDY Organizational Performance}

The concept of performance can be defined as the level of achievement of results. Performance is a result (output) of a certain process carried out by all organizational components against certain sources used (input)(Nofriansyah, 2018). In other words, performance is the result of a series of process activities carried out to achieve the goals of an organization. An organization is said to be high performance if the organization is able to produce a planned performance on quality improvement by utilizing great human resources. The organizational performance consists of the results obtained compared to work targets(MBN, 2019).Another opinion expressed by(Pasolong, 2015)organizational performance is the overall effectiveness of the organization for the interests determined by each organization related to systemic activities in increasing organizational expertise continuously to achieve effective and efficient expectations.

The latest development of the concept of performance is popular with the term performance excellence which has a controlled approach to managing organizational performance whose results convey high value for utilization that contributes to the achievement of organizational success, improvement of overall organizational effectiveness and capacity, and the concept of educating organizations and members. The concept of performance now provides a design and assessment medium in analyzing the organization's capabilities and opportunities to improve so that it becomes a work program guideline. In this research, the measurement of organizational performance uses indicators as disclosed by(Pasolong, 2015)namely productivity, service quality, responsiveness, responsibility, and accountability.

\section{Human Capital}

The role of human resources (human capital) is very important in the activities of an organization, so an organization needs to manage human resources as well as possible because the key to the success of an organization is not only the excellence of technology and available funds but also its human factors(Sukoco \& Prameswari, 2017). Human capital is unique and 


\section{International Journal of Business Management and Economic Review}

Vol. 4, No. 03; 2021

ISSN: 2581-4664

different from other capital. This is necessary for companies to achieve goals, develop and stay innovative. Human resources are intangible assets or qualities that are not listed on the company's balance sheet(Kenton, 2019). Companies can invest in human resources, for example through education and training which allows for increased quality and production. Human capital is defined as humans themselves who are personally loaned to institutions with individual capabilities, commitments, knowledge, and personal experiences.

Human capital is a very strong concept that has the potential to bring about a fundamental and radical change in the way organizations, both public and private, manage their people(Kearns, 2019).(Rahman, Maesaroh, \& Djumiarti, 2014)mentioned that there are several factors that influence human capital, namely knowledge, skills, self-concept, personal characteristics, and motives. In this research, the measurement of human capital uses indicators as disclosed by(Schermerhorn, 2013)namely skills, innovation, creativity, life experience, and knowledge

\section{Transformational leadership}

Leadership in an organization is an important factor in determining the achievement of the goals set by the organization. A leader is a person who has responsibility for decision making, implementing policy direction, supervising, motivating, communicating, and directing his subordinates in running an organization so that they can achieve the goals and objectives of the organization. Leadership style is the way leaders behave in exercising their authority. According to(Northouse, 2013)leadership style is a set of characteristics used by leaders to influence subordinates in achieving organizational goals or objectives.(Robbins \& Judge, 2017)said that transformational leadership is a leader who provides consideration and intellectual stimulation that is individualized and has charisma. According to(Colquitt, LePine, \& Wesson, 2011)transformational leadership includes inspiring followers to commit to a shared vision that gives meaning to their work while also serving as role models helping followers develop potential and see their problems from new perspectives.

Transformational leadership style is very good to be applied in organization because in this leadership style it includes charismatic values, intellectuality, inspiration, and individual attention so that it can be positive towards the performance of both employee and organizational performance(Maidawati, Musnadi, \& Ali, 2019).In this research, transformational leadership is measured using indicators as expressed by(Robbins \& Judge, 2014)namely charisma, inspiration, intellectual stimulation, individualized consideration.

\section{Knowledge Management}

(Harsono, Musnadi, \& Putra, 2020)revealed in the modern economy, organizations that make use of knowledge are organizations that have a competitive advantage. (Mahfud, 2016)suggested that the main processes in knowledge management include knowledge creation, knowledge utilization, and knowledge sharing. Knowledge management is a series of activities used by organizations both institutions and companies to identify, create, explain and apply knowledge to be reused, known, and studied so as to create organizational goals.(Adzima \& Sjahruddin, 2019).

While(Idris, Jamali, \& Sjahruddin, 2019)argued that knowledge management is an effective process related to exploration, exploitation, and sharing of human knowledge using 


\section{International Journal of Business Management and Economic Review}

Vol. 4, No. 03; 2021

ISSN: 2581-4664

appropriate technology and a cultural environment to increase intellectual capital and employee performance. In this research, measurementused the indicators revealed by (Groff \& Jones, 2003)namely (1) use of knowledge, (2) sharing of knowledge, (3) reflection of knowledge, and (4) identification of knowledge.

\section{Conceptual Framework and Hypotheses}

This conceptual framework and research hypothesis are described as follows :

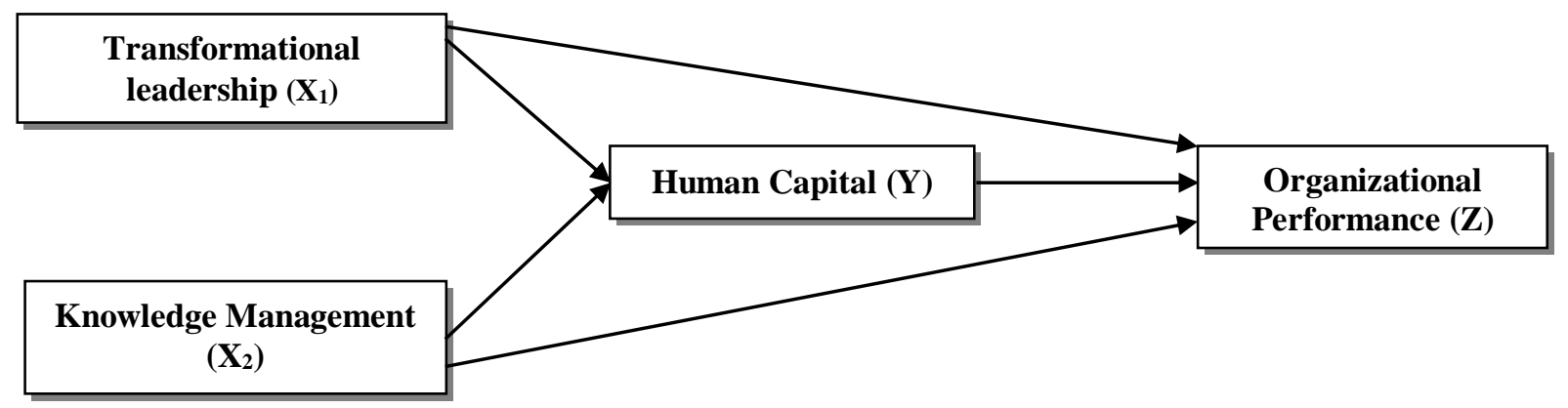

Figure 1. Conceptual Framework

Descriptive Hypothesis

Ha1: Transformational Leadership, Knowledge Management, Human Capital, and BPKA Organizational Performance are good.

Verification Hypothesis

Ha2: Transformational leadership affects Human Capital

Ha3: Knowledge Management affects Human Capital

Ha4: Transformational Leadership affects Organizational Performance

Ha5: Knowledge Management affects Organizational Performance

Ha6: Human Capital affects Organizational Performance

Ha7: Transformational Leadership affects Organizational Performance through Human Capital.

Ha8: Knowledge Management affects Organizational Performance through Human Capital.

\section{RESEARCH METHOD}

This research was conducted at BPKA. The research objects were Transformational Leadership, Knowledge Management, Human Capital, and Organizational Performance. In this research, the population was all civil servants (PNS) at BPKA, amounting to 378 people. This research established Stratified Proportional Random Sampling as a method of sampling based on the BPKA work unit group. Meanwhile, the minimum number of sample in this research was determined using the Slovin formula(Umar, 2011), provided as many as 131 respondents. Based on the work unit, the population and sample numbers in BPKA are shown in table 3 below. 


\section{International Journal of Business Management and Economic Review}

Vol. 4, No. 03; 2021

ISSN: 2581-4664

\section{Table 3. Population and Sample}

\begin{tabular}{|c|c|c|c|c|}
\hline No. & Field & Population & $\begin{array}{l}\text { sample } \\
\text { proportion }\end{array}$ & Sample \\
\hline 1 & Secretariat & 60 & $\begin{array}{lll} & \frac{60}{378} & x\end{array}$ & 21 \\
\hline 2 & Income Sector & 32 & $131 \quad \frac{32}{378} \quad x$ & 11 \\
\hline 3 & Aceh Budget Sector & 17 & $\frac{17}{378} \times 131$ & 6 \\
\hline 4 & Aceh Property Management Sector & 29 & $\frac{29}{378} \times 131$ & 10 \\
\hline 5 & Treasury Sector & 28 & $\frac{28}{378} \times 131$ & 10 \\
\hline 6 & Accounting Sector & 19 & $\frac{19}{378} \times 131$ & 7 \\
\hline 7 & $\begin{array}{l}\text { Field of Development and Budget } \\
\text { Evaluation }\end{array}$ & 16 & $\frac{16}{378} \times 131$ & 6 \\
\hline 8 & UPTD & 177 & $\frac{177}{378} \times 131$ & 60 \\
\hline \multicolumn{2}{|c|}{ Total Research Sample } & 378 & & 131 \\
\hline
\end{tabular}

Source: Processed (2020)

The research used data collection technique with a questionnaire, by using questions related to the variables studied. The answers have been adjusted to the perceptions of each respondent through a Likert scale. Data were analyzed through the use of Structural Equation Modeling (SEM). Mathematically, the causality relationship between constructs in research can be stated as follows:

Human Capital $(\eta 1)=\gamma 11$ Transformational leadership $+\gamma 12$ Knowledge Management $+\zeta 1$ Organizational Performance $(\eta 2)=\gamma 21$ Transformational leadership $+\gamma 22$ Knowledge Management $+\beta 21$ Human Capital $+\zeta 2$

Testing was done in 3 (three) ways, namely descriptive hypothesis testing, direct effect hypothesis testing, and indirect effect hypothesis testing with human capital as the mediating variable. Testing the mediating effect in this research used an approach(Baron \& Kenny, 1986), through Sobel test to assess the degree of significance.

\section{RESULT}

\section{Descriptive hypothesis testing}

The results of respondents' perceptions are described in table 2 below. 
International Journal of Business Management and Economic Review

Vol. 4, No. 03; 2021

ISSN: 2581-4664

Table 4. Recapitulation of Respondents' Perceptions of Variables

\begin{tabular}{|l|l|l|l|l|}
\hline No & Variable & Average & Cut off & Information \\
\hline 1 & Organizational Performance (Z) & 4.18 & & Good \\
\hline 2 & Human Capital (Y) & 3.94 & \multirow{3}{*}{3,41} & Good \\
\cline { 1 - 2 } 3 & Transformational Leadership (X1) & 3.92 & & Good \\
\cline { 1 - 2 } 4 & Knowledge Management (X2) & 4.19 & & Good \\
\hline
\end{tabular}

Source: Processed data (2021)

Based on the data in table 4, it is revealed that the respondents' perceptions of all variables in this research are already in good condition where all of these variables have obtained a mean value greater than 3.41. The next step is to do statistical testing using one sample T-test using a significant value $(\alpha=5 \%)$ and a cut-off value of 3.41. The criterion of this test is that if the significant value of the test is greater than 0.05 , the results of the descriptive hypothesis testing are that $\mathrm{HO}$ is accepted and $\mathrm{Ha}$ is rejected. Likewise, if the test results show a significant value smaller than 0.05 , then $\mathrm{HO}$ is accepted and $\mathrm{Ha}$ is rejected. Table 5 below shows the results of the one-sample test.

Table 5. Testing One-Sample T-Test

\begin{tabular}{|c|c|c|c|c|c|c|}
\hline & \multicolumn{6}{|c|}{ Test Value $=3.41$} \\
\hline & \multirow[t]{2}{*}{$\mathrm{T}$} & \multirow[t]{2}{*}{ df } & \multirow{2}{*}{$\begin{array}{l}\text { Sig. } \\
\text { tailed) }\end{array}$} & \multirow{2}{*}{$\begin{array}{l}\text { Mean } \\
\text { Difference }\end{array}$} & \multicolumn{2}{|c|}{$\begin{array}{l}\text { 95\% Confidence Interval of } \\
\text { the Difference }\end{array}$} \\
\hline & & & & & Lower & Upper \\
\hline $\mathrm{TL}$ & 7.703 & 130 & .000 & .50794 & .3775 & .6384 \\
\hline KM & 14.051 & 130 & .000 & .77511 & .6660 & .8842 \\
\hline $\mathrm{HC}$ & 8.498 & 130 & .000 & .52588 & .4034 & .6483 \\
\hline $\mathrm{OP}$ & 14.542 & 130 & .000 & .76557 & .6614 & .8697 \\
\hline
\end{tabular}

Source: Processed data (2021)

The test results of one-sample t-test with a test value $=3.41$ as shown in table 5 above, it is known that all variables show a sig value. (2-tailed) of $0.000<0.05$. With this, it can be concluded that the results of the descriptive hypothesis testing $(\mathrm{H} 1)$ are accepted where Ha1 is accepted and Ho1 is rejected. These results can be interpreted that transformational leadership, knowledge management, human capital, and organizational performance at BPKA are already in good condition.

\section{Direct Hypothesis Testing}

The structural model analysis explaining the effect test between variables is presented in the following path diagram: 


\section{International Journal of Business Management and Economic Review}

Vol. 4, No. 03; 2021

ISSN: 2581-4664

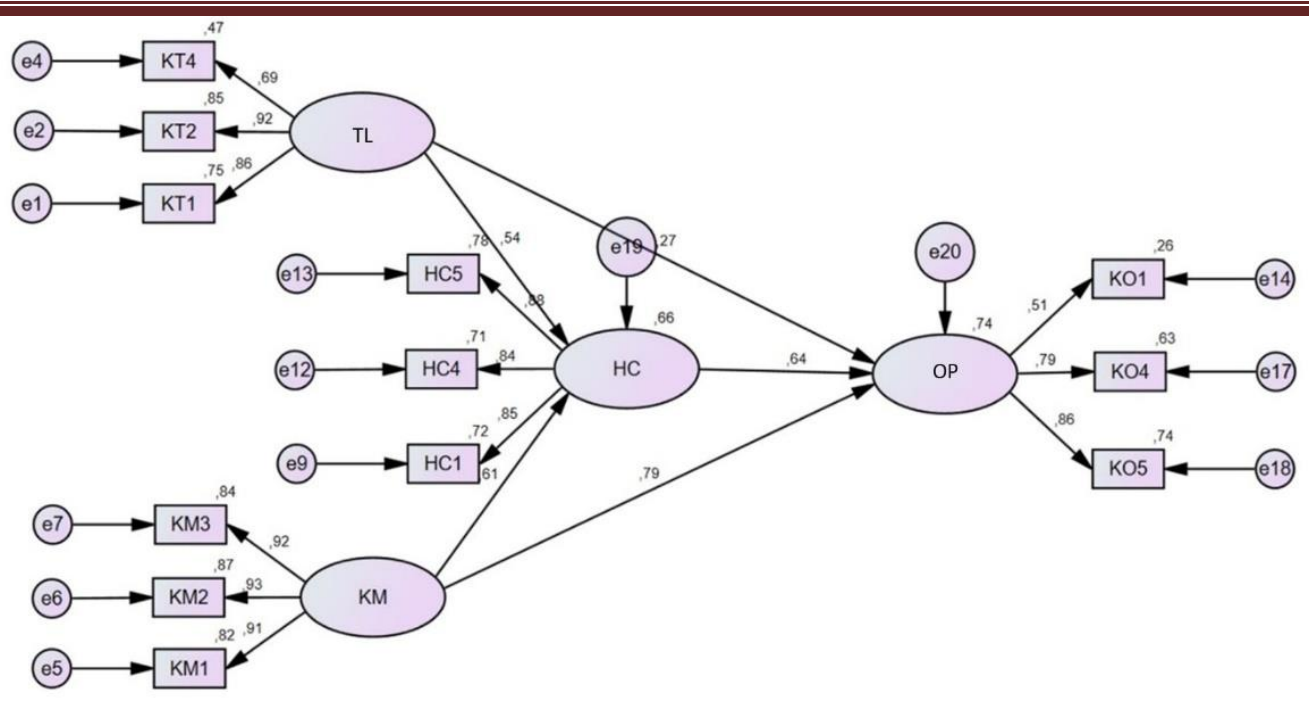

Figure 2. Full SEM Model

The full model for testing the direct effect hypothesis after fulfilling the SEM assumptions are more clearly shown in table 6 below:

Table 6. Direct Hypothesis Test Results

\begin{tabular}{|lll|l|l|l|l|l|}
\hline & & & Estimate & \multirow{2}{*}{ S.E. } & \multirow{2}{*}{ C.R. } & P \\
\hline & & & Standardized & Unstandardized & & & \\
\hline HC & $<---$ & TL & .535 & .428 & .061 & 7.076 & $* * *$ \\
\hline HC & $<---$ & KM & .611 & .467 & .057 & 8.171 & $* * *$ \\
\hline OP & $<--$ & TL & .268 & .107 & .044 & 2.433 & .015 \\
\hline OP & $<---$ & KM & .794 & .303 & .041 & 5.675 & $* * *$ \\
\hline OP & $<---$ & HC & .637 & .317 & .084 & 3.749 & $* * *$ \\
\hline
\end{tabular}

Source: Primary data, 2021 (processed)

Keterangan:

$\mathrm{OP}=$ Organizational Performance

$\mathrm{HC}=$ Human Capital

KT $=$ Transformasional Leadership

$\mathrm{KM}=$ Knowledge Management

From the test findings in table 6 , it can be described as follows:

1. H2: Testing the effect of transformational leadership on BPKA human capital obtained a critical ratio (C.R) value of 7.076 where this value is greater than the cut-off value of 1.96 . The $\mathrm{p}$-value 0.000 is smaller than 0.05 . These values prove that transformational leadership has a significant effect on BPKA's human capital. The amount of direct effect of transformational leadership on human capital can be seen from the acquisition of an 
Vol. 4, No. 03; 2021

ISSN: 2581-4664

estimated value of 0.535 , which means that the amount of direct influence is $53.5 \%$. Thus, the hypothesis testing $(\mathrm{H} 2)$ is accepted, which results in $\mathrm{Ha} 2$ being accepted and $\mathrm{H} 02$ being rejected. The results of this research are in line with the results of research that has been conducted(Sijabat \& Aseanty, 2020), (Pasamar, Diaz-Fernandez, \& Rosa-Navarro, 2019), (Alnajdawi, Hanandeh, Barhem, \& Mohammed, 2019), (Rajak, Thahrim, \& Pinoa, 2018), (Koednok, 2013)and(Birasnav, Rangneka, \& Dalpati, 2010)where the results of their research showed that transformational leadership style has a significant effect on human capital.

The results of this research indicate that the better the transformational leadership style is applied, the better the human capital produced at BPKA. Transformational leadership can change a new paradigm in the organization it manages. Therefore, to lead to change, this leadership style is very important to be applied in leading an organization, especially BPKA, because this style always clings to the vision in achieving the ultimate goals of the organization. Transformational leadership is more innovation-oriented and will encourage generalist human capital(Pasamar et al., 2019). Based on the opinions given by respondents of BPKA employees, there are several things that need to be improved in terms of transformational leadership to increase human capital. These things are individual considerations, intellectual stimulation. Thus, the transformational leadership style applied by BPKA can encourage the professional growth of employees in order to achieve the benefits of human capital.

2. H3: Testing the influence of Knowledge Management on BPKA human capital obtained a C.R value of 8.171 where this value is greater than the cut-off value, which is 1.96 . The pvalue of 0.000 is smaller than 0.05. These values prove that Knowledge Management has a significant effect on BPKA's human capital. From the results of direct hypothesis testing, it is also known that the estimated value is 0.611 , meaning that the amount of direct influence of Knowledge Management on human capital is $61.1 \%$. Thus the results of hypothesis testing (H3) are accepted which results in $\mathrm{Ha} 3$ accepted and $\mathrm{H} 03$ rejected. The results of this research are in line with the results of research conducted by(Hasbi, 2020), (Umar, Musnadi, \& Nurdasila, 2020), (Alnajdawi et al., 2019), and(Gutowska, 2018)where the results of their research proved that knowledge management has a significant effect on human capital.

The results of this research also show that the better the knowledge management possessed by employees, the better the human capital in the organization, especially at BPKA. To create reliable human capital, BPKA leaders and/or management must continue to improve knowledge management. Things that must be considered in efforts to improve knowledge management are the use of knowledge, identification of knowledge, the reflection of knowledge, and sharing of knowledge of employees. Knowledge can be interpreted as a combination of experiences obtained through environmental information and systematic expertise acquired by new experiences. Human capital can be supported by knowledge management because knowledge management can be a strategic asset for an organization. Therefore, the knowledge management process to increase human capital is needed in achieving organizational goals.

3. H4: Testing the effect of transformational leadership on BPKA organizational performance obtained C.R results of 2.433> 1.96 and a p-value of $0.015<0.05$. These results indicate 


\section{International Journal of Business Management and Economic Review}

Vol. 4, No. 03; 2021

ISSN: 2581-4664

that the results of testing hypothesis 3 (H3) are transformational leadership has a significant effect on organizational performance or Ha4 is accepted and Ho4 is rejected. The amount of leadership influence on the organizational performance of BPKA is 0.268 or $26.8 \%$. The results of this research are in line with the results of research conducted by(Mukhtar, Risnita, \& Prasetyo, 2020), (Ikhsan, Adam, \& Faisal, 2019), (Atan \& Mahmood, 2019), (Arif \& Akram, 2018), (Toufaili, 2017), (Orabi, 2016)and(García-Morales, JiménezBarrionuevo, \& Gutiérrez-Gutiérrez, 2012)where the results of their research also proved that transformational leadership has a significant effect on organizational performance.

The results of this research prove that the better the role of transformational leadership, the better the resulting organizational performance, especially BPKA. Based on the theoretical study and the results of this research, it can be explained that transformational leadership at BPKA can motivate other parties to continue to excel in achieving the goals of an organization. With this, in the end, transformational leadership will result in a high level of cohesion, commitment, trust, motivation, and organizational performance. The results of the study provide evidence that transformational leadership styles also contribute substantially to organizational performance. These results add to the understanding of the role of transformational leadership styles in contributing to higher organizational productivity and performance. The ability of transformational leadership in inspiring employees is an important point in creating the achievement of organizational goals.

4. H5: Testing the influence of knowledge management on the organizational performance of BPKA obtained a C.R value of 5.675 where the C.R value is greater than the cut-off value, namely 1.96 and a p-value of $0.000<0.05$. These results indicate that knowledge management has a significant effect on BPKA organizational performance or the results of testing hypothesis 5 (H5) are that Ha5 is accepted and Ho5 is rejected. The influence of knowledge management on the organizational performance of BPKA is 0.794 or $79.4 \%$. The results of this research are in line with the results of research conducted by(Ramdani \& Hadijah, 2020), (Harsono et al., 2020), (Payal, Ahmed, \& Debnath, 2019), (Puryantini et al., 2017), (Samsiah \& Marlina, 2017), (Falah \& Prasetya, 2017), and(Torabi \& El-Den, 2017)Where the results of their research showed that knowledge management has a significant influence and has an important role in improving the performance of an organization.

From the results of literature studies and research results, it can be explained that knowledge management is a valuable asset that helps decision-making. The better knowledge management in an organization, the better the resulting organizational performance will be. In this case, decisions are of course strategic, tactical, or operational in nature, so the need for knowledge is contextual according to the goals of an organization in innovating, an organization can improve knowledge management because the better or higher knowledge management an employee has, the better the performance the resulting organization. Through the use of knowledge management, which is supported by superior employees who are managed professionally, it will produce the expected innovation and ultimately have an impact on organizational performance.

5. H6: Testing the effect of human capital on the organizational performance of BPKA obtained a C.R value of 3.749, greater than the cut-off value of 1.96 and a p-value of $0.000<0.05$. These results indicate that human capital has a significant effect on the organizational 
Vol. 4, No. 03; 2021

ISSN: 2581-4664

performance of BPKA or Ha6 is accepted and Ho6 is rejected. The magnitude of the influence of human capital on organizational performance is 0.637 or $63.7 \%$. The results of this research are in line with the results of research conducted by(Fernando, Yusoff, Khatibi, \& Azam, 2020), (Harsono et al., 2020), (Radianto \& Gumanti, 2019), (Pasamar et al., 2019), (Abdow, Guyo, \& Odhiambo, 2018), (Ali \& Chaudhry, 2017), (Deniz, Cimen, Atan, \& Kaya, 2017), (Afrah, 2016), (Awan \& Sarfraz, 2013), (Jamal \& Saif, 2011)where the results of their research showed that human capital has a significant effect on the performance of the organization/company.

The results of this research also show that the better the human capital of an organization will be able to have a positive impact on the achievement of an organization's goals, especially in realizing the targets that have been set. BPKA really needs a stable condition, but always experiences changes where these changes can destabilize the foundations that have been built in achieving its goals. In order for the organization to achieve its goals, employees must be able to increase their competence in accordance with the demands of change. Human capital development is not the same as intellectual capital development. In developing human capital, it is not only about providing knowledge and skills for employees but leaders must also be able to increase employee commitment because humans as organizational human capital are active objects where they have the desire and ability to determine where they work. This added value really depends on the ability of the human resources in the organization. Therefore, BPKA must be able to improve the skills and abilities of its employees by encouraging individual and organizational learning to be able to achieve the goals of the organization.

\section{Indirect Hypothesis Testing (Mediation)}

The results of testing the indirect hypothesis (mediation) are described below:

1. H7: Testing the Influence of Transformational Leadership on BPKA Organizational Performance through Human Capital. To see the effect of transformational leadership on organizational performance through the human capital of BPKA in this research used a Sobel test calculator. The test results using a single calculator for testing hypothesis 7 in this research are as shown in Figure 3 below.

\begin{tabular}{|c|c|c|c|c|}
\hline Input: & & Test statistic: & Std. Error: & $p$-value: \\
\hline a 0.428 & Sobel test: & 3.32356991 & 0.04082237 & 0.00088873 \\
\hline$b 0.317$ & Aroian test: & 3.29769365 & 0.04114269 & 0.00097482 \\
\hline$s_{a} 0.061$ & Goodman test: & 3.35006503 & 0.04049951 & 0.00080793 \\
\hline$s_{\mathrm{b}} 0.084$ & Reset all & & Calculate & \\
\hline
\end{tabular}

Figure 3. Sobel Test of Hypothesis 7

From the results of hypothesis testing, the indirect effect of transformational leadership on the organizational performance of BPKA through human capital shows a statistical test result of 3.323 where this value is greater than the cut-off value of 1.96 . The p-value is 0.000 $<0.05$. These results indicate hypothesis testing 7 is accepted where Ha7 is accepted and $\mathrm{H} 07$ is rejected. So with this proves that human capital mediates the effect of 


\section{International Journal of Business Management and Economic Review}

Vol. 4, No. 03; 2021

ISSN: 2581-4664

transformational leadership on BPKA organizational performance. Based on the results of the significance calculation for path $\mathrm{C}$ 'using the Sobel test, it can be illustrated visually for all paths $\mathrm{A}, \mathrm{B}, \mathrm{C}$, and $\mathrm{C}^{\prime}$ to test the indirect effect of transformational leadership on organizational performance through human capital as shown in the following figure.

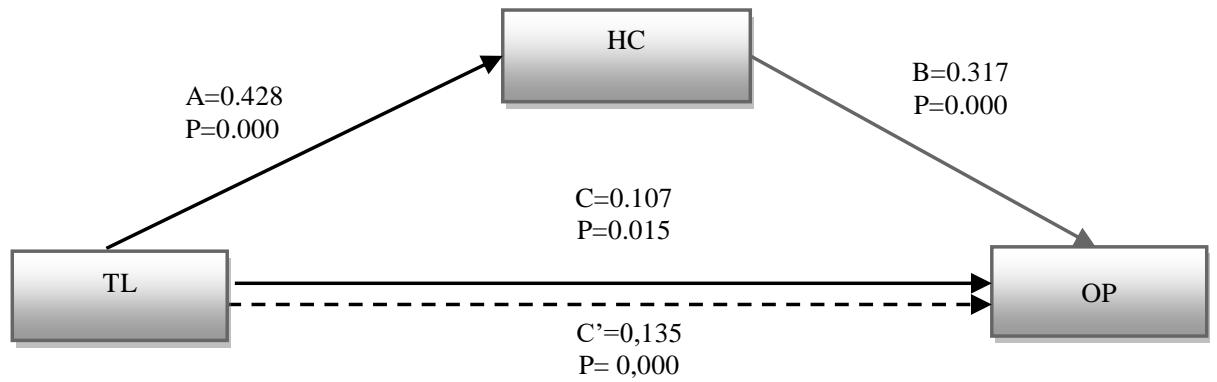

Figure 4. Hypothesis 7 Test Result

Based on Figure 4 above, it explains that the transformational leadership variable on human capital explains the coefficient value of path $A$ has a value of $\beta=0.428$ and a value of $p=$ $0.000<0.05$. The coefficient value of path $\mathrm{B}$ or the effect of human capital on organizational performance has a $\beta$ value of 0.317 and a $p$-value $=0.000<0.05$. The relationship between transformational leadership and organizational performance explains that the path coefficient value of $C$ has a value of $\beta=0.107$ and a value of $p=0.015<0.05$. and path $C$ 'or the relationship of transformational leadership to organizational performance through human capital has a value of $\beta=0.135(0.428 \times 0.317=0.135)$ and a value of $p=0.000<0.05$. From the values mentioned above, it shows that pathways $\mathrm{A}, \mathrm{B}, \mathrm{C}$ and $\mathrm{C}$ 'are significant or often referred to as partial mediation, in other words, in this research, human capital acts as partial mediation. The magnitude of the role of human capital mediation on the influence of transformational leadership on BPKA organizational performance is 0.135 or $13.5 \%$

2. H8: Testing the Influence of Knowledge Management on BPKA Organizational Performance through Human Capital. The results of testing hypothesis 8, namely the influence of knowledge management on BPKA organizational performance through human capital as shown in Figure5 below

\begin{tabular}{|c|c|c|c|c|}
\hline Input: & & Test statistic: & Std. Error: & $p$-value: \\
\hline a 0.467 & Sobel test: & 3.42766932 & 0.04318941 & 0.00060879 \\
\hline b 0.317 & Aroian test: & 3.40679838 & 0.043454 & 0.0006573 \\
\hline$s_{a} 0.057$ & Goodman test: & 3.4489286 & 0.04292318 & 0.00056282 \\
\hline$s_{b} 0.084$ & Reset all & & Calculate & \\
\hline
\end{tabular}

Figure 5. Sobel Test of Hypothesis 8

Based on the indirect hypothesis testing, the effect of knowledge management on 


\section{International Journal of Business Management and Economic Review}

Vol. 4, No. 03; 2021

ISSN: 2581-4664

organizational performance through human capital obtained a statistical test result of 3.427> 1.96 and a $\mathrm{p}$-value of $0,000<0.05$. These results indicate that the results of testing hypothesis 8 are accepted where $\mathrm{Ha} 8$ is accepted and H08 is rejected or human capital mediates the influence of knowledge management on BPKA organizational performance. Based on the results of the significance calculation for line C 'using the Sobel test, it can be illustrated visually for all paths $\mathrm{A}, \mathrm{B}, \mathrm{C}$, and $\mathrm{C}^{\prime}$ to test the indirect effect of knowledge management on BPKA organizational performance through human capital as shown in the following figure.

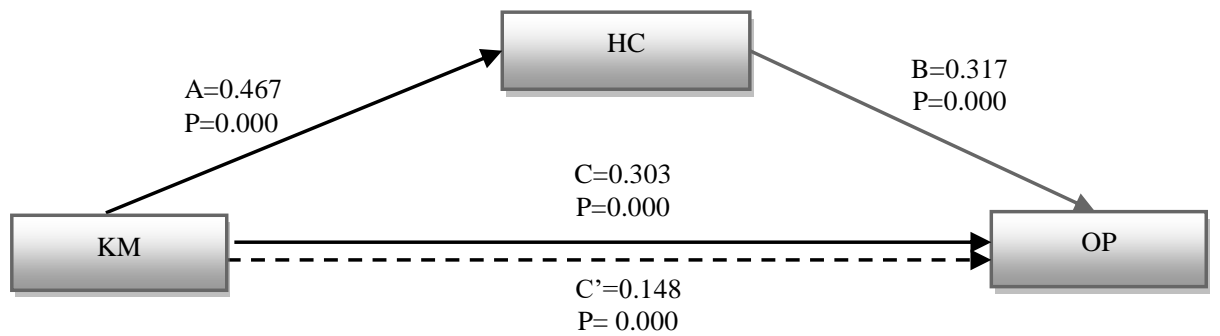

Figure 6.Hypothesis 8 Test Result

Based on Figure 6 above, it can reveals that the variable knowledge management on human capital explains the coefficient value of path $A$ has a value of $\beta=0.467$ and a value of $p=$ $0.000<0.05$. The coefficient value of path $\mathrm{B}$ or the effect of human capital on organizational performance has a $\beta$ value of 0.317 and a $p$-value $=0.000<0.05$. The relationship between knowledge management and organizational performance explains that the path coefficient value of $C$ has a value of $\beta=0.303$ and a value of $p=0.000<0.05$ and path $C$ 'or the relationship between knowledge management and organizational performance through human capital has a value of $\beta=0.148(0.467 \times 0.317=0.148)$ and a value of $p=0.000$ $<0.05$. From the values of the above test results indicate that the paths $\mathrm{A}, \mathrm{B}, \mathrm{C}$, and $\mathrm{C}$ 'are significant. This result is often referred to as partial mediation, in other words, in this research, human capital acts as partial mediation. The magnitude of the role of human capital mediation on the influence of knowledge management on BPKA organizational performance is 0.148 or $14.8 \%$.

\section{CONCLUSION}

The results of testing the descriptive hypothesis, namely transformational leadership, knowledge management, human capital, and BPKA organizational performance, have obtained good results. This can be seen as a whole that the mean value of respondents' perceptions of the research variables is $4.05>3.41$ and the probability value for all variables is $0.000<0.05$. The results of direct hypothesis testing prove that personal transformation leadership and knowledge management have a significant effect on human capital, and transformational leadership, knowledge management, and human capital have a significant effect on BPKA organizational performance. The results of hypothesis testing indirectly prove that human capital plays a role as partial mediation both in mediating the role of transformational leadership on organizational performance and in mediating knowledge management on organizational performance at BPKA. 


\section{International Journal of Business Management and Economic Review}

Vol. 4, No. 03; 2021

ISSN: 2581-4664

All of these results prove that modeling to improve BPKA's organizational performance can be used. This can be a reference both academically and practically. Further researchers can use this proven research model for further research development, by adding other variables such as organizational citizenship behavior (OCB) and high-performance working systems (HPWS).

Human capital at BPKA needs to be continuously improved because as is known from the results of this research where both directly and indirectly, human capital has a positive and significant impact on organizational performance. In order to increase human capital, BPKA leaders must be able to improve their abilities (Skills) and develop innovation and creativity from each employee either by allocating a special budget for providing self-development training for employees or the opportunity to attend workshops or trainings that are able to provide or improve abilities self, both employees' intelligence quotient (IQ) and emotional quotient (EQ). With employees who have reliable human capital, it will make it easier for BPKA leaders to determine positions or fields for each employee according to their abilities. So that it can maximize the ability of employees to achieve the goals of the organization.

Although based on the results of respondents' perceptions of BPKA's transformational leadership, its implementation needs to be further improved because this leadership style has a positive and significant impact on human capital and organizational performance. The most important thing to get attention or need to be improved is individualized consideration because based on the respondents' perceptions, this indicator gets the lowest average value, namely 3.58. With the increase in this indicator, it will be able to make employees feel comfortable at work and even in discussing every work problem at hand, inspiring employees about ways to see problems that are very difficult for employees, telling employees how to do work properly. Good and correct in a way that is easy to understand and can prevent employees from making their own decisions when there are problems. In addition, leaders in the BPKA environment in applying a transformational leadership style, really need to be able to continue to improve their intellectual abilities.

Knowledge management needs to be continuously improved because with the continuous development and improvement of knowledge management from each employee so that the excellence of the employees can be created and of course will have a positive impact in efforts to improve and achieve the goals of the organization. The things that need to be done by the leadership and structural ranks in the organization, especially at BPKA, are to carry out a comprehensive evaluation, starting from the use of knowledge, sharing knowledge, reflecting on knowledge and identifying knowledge for each employee. With the results of this evaluation, leaders and structural ranks at BPKA can adjust knowledge management, integrate infrastructure and design existing knowledge management teams to create strategies for achieving organizational goals. BPKA leaders must provide opportunities and provide support by providing more budget for development for their employees through the opportunity to attend seminars, short courses, education, and training.

BPKA leaders must also be able to align employee knowledge management so that employees can develop innovations in carrying out their daily tasks. In addition, with the development of employees in the field of technology, information, and communication, it will be able to form strong fundamentals for developing knowledge management so that it can produce much better organizational performance. 
Vol. 4, No. 03; 2021

ISSN: 2581-4664

\section{REFERENCES}

Abdow, A. I., Guyo, W., \& Odhiambo, R. (2018). Influence of Human Capital Development on Organizational Change in the Petroleum Industries in Kenya. European Journal of Business and Management, 10(4), 9-14.

Adzima, F., \& Sjahruddin, H. (2019). Pengaruh Knowledge Management Terhadap Kinerja Pegawai. Jurnal Organisasi Dan Manajemen, 15(1), 58-68. https://doi.org/http://doi.org/10.5281/zenodo.3459964

Afrah, N. A. (2016). The Role of Human Capital Development on Organizational Performance: Case Study Benadir University, Mogadishu, Somalia. European Journal of Business and Management, 8(4), 120-124.

Ali, H., \& Chaudhry, I. S. (2017). Effect of Human Capital on Organization Performance: An Analysis from Service Sector of Punjab, Pakistan. European Online Journal of Natural and Social Sciences, 6(3), 475-481.

Alnajdawi, S., Hanandeh, R., Barhem, B. Y., \& Mohammed, A. (2019). Leadership, Knowledge Management, and Human Capital Development. Economics World, 7(3), 124-133. https://doi.org/10.17265/2328-7144/2019.03.002

Arif, S., \& Akram, A. (2018). Transformational Leadership and Organizational Performance. SEISENSE Journal of Management, 1(3), 59-75. https://doi.org/10.5281/zenodo.1306335

Atan, J. bin, \& Mahmood, N. H. N. (2019). The role of transformational leadership style in enhancing employees' competency for organization performance. Management Science Letters, 9, 2191-2020. https://doi.org/0.5267/j.msl.2019.7.033

Awan, M. A. S., \& Sarfraz, N. (2013). The Impact of human capital on Company performance and the mediating effect of employee's satisfaction. IOSR Journal of Business and Management (IOSR-JBM), 8(2), 76-82.

Baron, R. M., \& Kenny, D. A. (1986). The moderator-mediator variable distinction in social psychological research: Conceptual, strategic, and statistical considerations. Journal of Personality and Social Psychology, 51(6), 1173-1182. https://doi.org/10.1037//00223514.51.6.1173

Birasnav, M., Rangneka, S. N., \& Dalpati, A. (2010). Transformational leadership, interim leadership, and employee human capital benefits: an empirical study. Procedia - Social and Behavioral Sciences, 5, 1037-1042. https://doi.org/https://doi.org/10.1016/j.sbspro.2010.07.232

Colquitt, J. A., LePine, J. A., \& Wesson, M. J. (2011). Organizational. Behavior. New York: McGraw Hill.

Deniz, S., Cimen, M., Atan, O., \& Kaya, S. (2017). Effect Of Human Capital On Organizational Performance In Healthcare Organizations. 2nd World Conference on Technology, Innovation and Entrepreneurship, 34-38. https://doi.org/10.17261/Pressacademia.2017. 513

Falah, A. S. N., \& Prasetya, A. (2017). Pengaruh Knowledge Management Terhadap Kinerja 
Vol. 4, No. 03; 2021

ISSN: 2581-4664

Karyawan Dan Kinerja Perusahaan (Studi pada Karyawan PT Semen Indonesia Persero Tbk). Jurnal Administrasi Bisnis, 50(4), 192-198.

Fernando, W. H. M., Yusoff, S. K. M., Khatibi, A., \& Azam, S. M. F. (2020). Human Capital Impact On Organizational Performance: Special Reference To The Banks In Sri Lanka. European Journal of Social Sciences Studies, 5(1), 99-115. https://doi.org/10.5281/zenodo.3747853

García-Morales, V. J., Jiménez-Barrionuevo, M. M., \& Gutiérrez-Gutiérrez, L. (2012). Transformational leadership influence on organizational performance through organizational learning and innovation. Journal of Business Research, 65(7), 1040-1050. https://doi.org/https://doi.org/10.1016/j.jbusres.2011.03.005

Groff, T. R., \& Jones, T. P. (2003). Introduction to Knowledge Management: KM in Business. Oxford: Butterworth-Heinemann.

Gutowska, J. (2018). Leadership and Knowledge Management: Mapping Intersections with Keywords Analysis. Journal of Corporate Responsibility and Leadership, 5(1), 23-43. https://doi.org/http://dx.doi.org/10.12775/JCRL.2018.002

Harsono, Musnadi, S., \& Putra, T. R. I. (2020). The Effect of Knowledge Sharing and Knowledge Management on Performance of Stain Gajah Putih Mediated by Job Satisfaction. International Journal of Scientific and Management Research2, 3(3), 35-47.

Hasbi, A. (2020). Pengaruh Knowledge Management terhadap Pengembangan Sumber Daya Manusia dan Kinerja Karyawan Perhotelan di Sulawesi Selatan. Kawistara: The Journal of Social Sciences and Humanities, 10(2), 199-220. https://doi.org/https://doi.org/10.22146/kawistara.56756

Idris, M. H., Jamali, H., \& Sjahruddin, H. (2019). Investigating the moderating role of knowledge: The relationship between auditor's experience and ethical judgment. Advances in Social Sciences Research Journal, 6(2), 491-503. https://doi.org/10.14738/assrj.62.6193.

Ikhsan, M., Adam, M., \& Faisal. (2019). The Effect of Transformational Leadership Style and Work Motivation on Job Satisfaction and Employee's Performance of Aceh Education Agency. The International Journal of Business Management and Technology, 3(4), 1-8.

Jamal, W., \& Saif, M. I. (2011). Impact of Human Capital Management on Organizational Performance. European Journal of Economics, Finance and Administrative Sciences, 34, $55-69$.

Kearns, P. (2019). What do we mean by Human Capital Management (HCM). In What's the Future for Human Capital? (pp. 2-9). London: Chartered Institute of Personnel and Development.

Kenton, W. (2019). Human Capital. Retrieved September 6, 2020, from Investopedia website: https://www.investopedia.com/terms/h/humancapital.asp

Koednok, S. (2013). Effective of Transformational Leadership in Human Capital Management for Creating a Sustainable ASEAN Community (AEC). Journal of Advanced Management Science, 1(1), 129-132. https://doi.org/10.12720/joams.1.1.129-132 


\section{International Journal of Business Management and Economic Review}

Vol. 4, No. 03; 2021

ISSN: 2581-4664

Mahfud, Y. (2016). Pengaruh Knowledge Manajement, Skill, Dan Attitude Terhadap Employee Performance (Studi Kasus Pada DPPKAD Kabupaten Banjarnegara). Jurnal Ilmiah Ekonomi Manajemen Dan Akuntansi, 12(1), 49-81.

Maidawati, C., Musnadi, S., \& Ali, S. (2019). The Effect of Transformational Leadership, and Organizational Learning Culture on Perceived Organizational Support and Its Impact on Employee Work Satisfaction in The Health Office of Pidie District. International Journal of Academic Reaserch in Economics and Management Sciences, 8(1), 27-36. https://doi.org/10.6007/IJAREMS/v8-i1/5468

MBN. (2019). Organizational performance - definition and meaning. Retrieved May 11, 2020, from Market Business News website: https://marketbusinessnews.com/financialglossary/organizational-performance-definition-meaning/

Modus-Aceh. (2019, July 24). Paripurna LKPJ Gubernur Aceh Tahun Anggaran 2019: Tak Sesuai Target dan Sulit Koordinasi, DPRA Minta Gubernur Pertimbangkan Penempatan Kepala BPKA. Modusaceh.Co. Retrieved from https://modusaceh.co/news/karena-tidaksesuai-target-dan-sulit-koordinasi-dpra-minta-gubernur-pertimbangkan-penempatan-kepalabpka/index.html

Mukhtar, Risnita, \& Prasetyo, M. A. M. (2020). The Influence of Transformational Leadership, Interpersonal Communication, and Organizational Conflict On Organizational Effectiveness. International Journal of Education Review, 2(1), 18-29.

Nofriansyah, D. (2018). Penelitian Kualitatif: Analisis Kinerja Lembaga Pemberdayaan Masyarakat Kelurahan. Yogyakarta: Deepublish.

Northouse, P. G. (2013). Leadership: Theory and Practice (6th ed.). Thousand Oaks: Sage Publications, Inc.

Orabi, T. G. A. (2016). The Impact of Transformational Leadership Style on Organizational Performance: Evidence from Jordan. International Journal of Human Resource Studies, 6(2), 89-102. https://doi.org/10.5296/ijhrs.v6i2.9427

Pasamar, S., Diaz-Fernandez, M., \& Rosa-Navarro, D. de la. (2019). Human capital: the link between leadership and organizational learning. European Journal of Management and Business Economics, 28(1), 25-51. https://doi.org/10.1108/EJMBE-08-2017-0003

Pasolong, H. (2015). Kepemimpinan Birokrasi (4th ed.). Bandung: Alfabeta.

Payal, R., Ahmed, S., \& Debnath, R. M. (2019). Impact of knowledge management on organizational performance: An application of structural equation modeling. VINE Journal of Information and Knowledge Management Systems, 49(4), 510-530. https://doi.org/https://doi.org/10.1108/VJIKMS-07-2018-0063

Puryantini, N., Arfati, R., \& Tjahjadi, B. (2017). Pengaruh Knowledge Management Terhadap Kinerja Organisasi Dimediasi Inovasi di Organisasi Penelitian Pemerintah. Berkala Akuntansi Dan Keuangan Indonesia, 2(2), 21-38.

Radianto, W. E., \& Gumanti, T. A. (2019). Human Capital Analysis Of Organizational Performance Mediated By Customer Capital: Case Of Accounting Study Program. 


\section{International Journal of Business Management and Economic Review}

Vol. 4, No. 03; 2021

ISSN: 2581-4664

International Journal Of Scientific \& Technology Research, 8(12), 3997-4000.

Rahman, A. H. L., Maesaroh, \& Djumiarti, T. (2014). Faktor-Faktor Yang Menentukan Pada Dimensi Human Capital Competencies Dalam Program Sertifikasi Guru Smk Negeri Di Kota Semarang. Journal Of Public Policy And Management Review, 3(4), 211-227. https://doi.org/10.14710/jppmr.v3i4.6570

Rajak, A., Thahrim, M., \& Pinoa, M. (2018). Pengaruh Human Capital Dan Kepuasan Kerja Terhadap Kinerja Pegawai Dinas Lingkungan Hidup Kota Ternate. Jurnal Manajemen Sinergi, 5(2), 1-20.

Ramdani, D. M., \& Hadijah, H. S. (2020). The Influence Of Knowledge Management On Organizational Performance With Erp Implementation As Mediator. Dinasti International Journal of Management Science, 1(4), 455-462. https://doi.org/https://doi.org/10.31933/dijms.v1i4.182

Robbins, S. P., \& Judge, T. A. (2014). Buku Perilaku Organisasi Buku 2 (Edisi ke-1; alih bahasa D. Angelica, Ed.). Salemba Empat.

Robbins, S. P., \& Judge, T. A. (2017). Essential of Organisational Behaviour (14th ed.). New Samsiah, S., \& Marlina, E. (2017). The Role Of Knowledge Management In Enhancing Performance University. Jurnal Akuntansi Dan Ekonomika, 7(1), 45-52.

Schermerhorn, J. R. (2013). Management (12th ED). America: Wiley.

Sijabat, P. M., \& Aseanty, D. (2020). The Influence of Transformational Leadership to Organizational Innovation and Explorative Learning Mediated by Generalist Human Capital at Oil Company. Proceedings of the International Conference on Management, Accounting, $\begin{array}{lll}\text { and Economy 2020), 340-342. } & \text { (ICMAE }\end{array}$ https://doi.org/https://doi.org/10.2991/aebmr.k.200915.076

Sukoco, I., \& Prameswari, D. (2017). Human Capital Approach to Increasing Productivity of Human Resources Management. Jurnal AdBispreneur, 2(1), 93-104.

Torabi, F., \& El-Den, J. (2017). The impact of Knowledge Management on Organizational Productivity: A Case Study on Koosar Bank of Iran. Procedia Computer Science, 124, 300310. https://doi.org/https://doi.org/10.1016/j.procs.2017.12.159

Toufaili, B. El. (2017). The Effects Of Transformational Leadership On Organizational Performance - A Theoretical Approach. Proceedings of the Internatioanl Management Conference, 153-163. Romania: The Role of Management in the Economic Paradigm of the XXIst Century.

Umar, H. (2011). Metode Penelitian untuk Skripsi dan Tesis Bisnis (Ed. 2). Depok: Raja Grafindo Persada.

Umar, Musnadi, S., \& Nurdasila. (2020). The Effect Of Sharing Knowledge On Human Capital And Its Impact On Organizational Innovation In Pidie Government Satker. International Journal of Business Management and Economic Review, 3(3), 17-29. 